\title{
Lições de gênero em pequenas doses
}

Beijo, boa sorte. RIBEIRO, Ana Elisa.

Natal: Jovens Escribas, 2015, 72p.

Pequenos textos, concisos e intensos. Fragmentos que bebem do cotidiano de diferentes mulheres daqui e dali, histórias que passeiam por toda parte: desde o quintal de nossa casa até lugares mais distantes, no espaço e no tempo. O livro Beijo, boa sorte, da escritora mineira Ana Elisa Ribeiro, é uma aula de gênero em pequenas lições; de fácil leitura, mas que nem por isso deixa de suscitar interessantes reflexões.

Os contos trazem para a pauta questões importantes quando pensamos em gênero, tais como a violência contra a mulher, a maternidade, o casamento, entre outras. Desse modo, a autora cria uma espécie de álbum de fotografias com imagens construídas a partir de diferentes vivências. Cada um deles possibilita compreender gênero como construção social conforme a concepção de Teresa de Lauretis, ou seja, os sujeitos sociais são também "constituídos por meio de códigos linguísticos e representações culturais; [...] engendrados não só na experiência de relações de sexo, mas também nas de raça e classe" (Teresa LAURETIS, 1994, p. 208).

As personagens de Beijo, boa sorte transitam por diferentes espaços e integram diferentes gerações. Da menina que desde cedo aprende, no espaço doméstico e ensinada pela própria mãe, as pedagogias da sexualidade de que nos fala Guacira Lopes Louro (2007), e que demonstra como os papéis de gênero são estabelecidos desde a infância e perpetuados nas relações familiares, até a mulher idosa que comemora a sua viuvez como o momento de maior libertação e felicidade, ainda que seja uma celebração silenciosa. Das prostitutas que vagam pelas ruas sem um lugar para thes oferecer proteção ou pelo menos um teto sob o qual dormir, às que enfrentam o preconceito por parte dos vizinhos no edifício em que moram, ou às que migraram para o exterior e de lá sustentam suas famílias, mas escondem a origem do dinheiro. Encontramos em Beijo, boa sorte a multiplicidade e a contradição desses sujeitos divididos, fragmentados, mas também únicos.

Dividido em duas partes, "com o rosto em retalhos" e "baú da avó", o livro se estrutura a partir de dois eixos: a temática da violência contra a mulher, ainda pouco explorada na literatura brasileira contemporânea, e a temática da memória e da infância, que recupera personagens comuns na maioria das famílias, como a tia que nunca se casou ou a avó que passa grande parte da vida de luto, entre outras figuras próprias do imaginário popular.

Apesar de problematizar essas representações, subvertendo-as em alguns momentos, como ocorre no conto teima, no qual uma noiva escreve um bilhete para o futuro marido informando-o de que não sabe desempenhar uma lista de tarefas domésticas tradicionalmente atribuídas às mulheres em uma sociedade patriarcal, e, ainda assim, o noivo decide se casar com ela, aceitando-a como ela é, o ponto forte do livro é, sem dúvida, a reflexão que ele propõe em relação à violência contra a mulher.

Ao apresentar a violência contra a mulher no cotidiano, destacando o espaço doméstico como aquele de maior vulnerabilidade, é que o livro de Ana Elisa Ribeiro se engrandece. Apesar dos altos números de casos de violência contra a mulher não apenas no Brasil, mas em todo o mundo, os incidentes de violência continuam sendo invisibilizados, quando não distorcidos, a ponto de culpar as próprias vítimas pela violência sofrida, situação exemplificada no conto incêndio: 
Não pus fogo no colchão por intenção, doutor. A ideia da vela foi ela quem teve. Acho que viu na televisão a vela em cima da cama. Vê-la carbonizada me lembrou muito aquelas velas votivas gastas. (Ana Elisa RIBEIRO, 2015, p. 24)

A invisibilidade de algumas formas de violência $e$, principalmente, uma maior ou menor (in)visibilidade da violência sofrida a depender de quem sejam as vítimas, têm sido discutidas por importantes pensadoras como Susan Sontag (2003) e Judith Butler (2015). Em um de seus trabalhos, Susan Sontag buscou refleti sobre o impacto que as fotografias de guerra causam em seus espectadores, evidenciando que a exposição a fotos violentas pode nos desumanizar ou, pelo menos, diminuir as nossas chances de sensibilização para os problemas que elas retratam. Quando pensamos na literatura brasileira contemporânea e no pouco destaque que a temática da violência contra a mulher tem tido, como podemos inferir de uma pesquisa mais ampla sobre os romances contemporâneos coordenada por Regina Dalcastagnè (2012), percebemos que cada vez mais se torna necessário colocar em pauta esse tema, principalmente em virtude da persistente violência de gênero em nossa sociedade.

Mesmo considerando as observações de Susan Sontag sobre o nosso posicionamento ético diante da dor dos outros e, no que tange à fotografia, à capacidade que ela tem de nos chocar e, com isso, apelar para o nosso senso de obrigação moral, é interessante ponderar a discussão retomada por Judith Butler, a partir da obra de Sontag, no livro Quadros de guerra. Para Sontag, as narrativas são os recursos mais eficazes para mobilizar as pessoas efetivamente contra a guerra (ou contra a violência que retratam), já que podem nos levar a compreender melhor determinada situação, ao passo que as imagens nos perseguem apenas quando consideramos que ali retratam uma vida passível de luto, mas podem também ser facilmente esquecidas, se consideramos que não há perda. Por sua vez, Butler considera que as imagens já constituem em si uma interpretação, estruturada pelo próprio enquadramento da fotografia e que não deixam de nos estimular ou enfurecer diante do que retratam. Os enquadramentos determinam o que deve ou não ser mostrado e orientam por si só uma determinada interpretação, que precisa ser sempre criticamente observada. Do ponto de vista da literatura, os enquadramentos que Butler menciona também se aplicam, no sentido de que certas escolhas sobre o que é representado nas obras literárias lou as ausências) refletem, por sua vez, uma visão de mundo. E quando pensamos em violência, em quais vidas são consideradas como vida, em quais vidas são passíveis de luto.

Segundo o relatório da Organização Mundial de Saúde de 2014 (WHO, 2014), uma em cada três mulheres são vítimas de violência física ou sexual por parceiro íntimo em algum momento de suas vidas, o que só comprova a necessidade urgente de discutir a questão da violência contra a mulher como um problema de saúde pública global. A literatura, enquanto espaço de representação, onde ideologias e discursos se manifestam, tem o papel de fomentar o debate e contribuir para uma reflexão sobre o mundo, primeiro passo para possíveis e desejáveis mudanças.

O miniconto a seguir, intitulado felizinhas, e com o qual escolho terminar este texto, ilustra algumas das reflexões levantadas no livro de Ana Elisa Ribeiro, demonstrando a sua pertinência: a relação entre gênero e violência que, de forma semelhante, também se apresenta como uma construção, algo que nos é ensinado e que permanece como um dos principais problemas na luta contra a violência - a dificuldade que muitas vítimas têm de reconhecer a violência vivida e lutar contra ela. Simplesmente porque assim foram ensinadas.

Lembro de minha mãe com algodão nas narinas e sete furos abaixo do seio esquerdo. Ornamentais. E também lembro da minha avó roxinha, roxa que nem repolho, com uns ornamentos no pescoço. E me ensinaram que elas eram felizes. (RIBEIRO, 2015, p. 17, grifo meu)

\section{Referências}

BUTLER, Judith. Quadros de guerra: quando a vida é passível de luto? Trad. de Sérgio Lamarão e Arnaldo Marques da Cunha. Rio de Janeiro: Civilização Brasileira, 2015.

DALCASTAGNÉ, Regina. Literatura brasileira contemporânea: um território contestado. Vinhedo: Horizonte, 2012.

LAURETIS, Teresa de. "A tecnologia do gênero". Tradução de Susana Bornéo Funck. In.: HOLLANDA, Heloísa Buarque de (Org.). Tendências e impasses: o feminismo como crítica da cultura. Rio de Janeiro: Rocco, 1994, p. 206-242.

LOURO, Guacira Lopes. "Pedagogias da sexualidade". In: (Org.) O corpo educado: pedagogias da sexualidade. Belo Horizonte: Autêntica, 2007, p. 9-34.

RIBEIRO, Ana Elisa. Beijo, boa sorte. Natal: Jovens Escribas, 2015. 
SONTAG, Susan. Diante da dor dos outros. São Paulo: Companhia das Letras, 2003.

WHO. The Global status report on violence prevention 2014. Disponível em: ww.who.int/ violence injury prevention/violence/ status_report/2014/en/. Acesso em 19/02/2016.
[Recebido em 23/02/2016

e aceito para publicação em 25/04/2016]

Paula Queiroz Dutra

Universidade de Brasília, Distrito Federal, Brasil 